\title{
Solar Energy Prospects in Bangladesh: Target and Current Status
}

\author{
Sazzad Hossain, Mohammad Maksudur Rahman \\ Department of Physics, Jahangirnagar University, Savar, Dhaka, Bangladesh \\ Email: sazzadju41@gmail.com, likhon_phy@yahoo.com
}

How to cite this paper: Hossain, S. and Rahman, M.M. (2021) Solar Energy Prospects in Bangladesh: Target and Current Status. Energy and Power Engineering, 13, 322-332.

https://doi.org/10.4236/epe.2021.138022

Received: July 5, 2021

Accepted: August 10, 2021

Published: August 13, 2021

Copyright $\odot 2021$ by author(s) and Scientific Research Publishing Inc. This work is licensed under the Creative Commons Attribution International License (CC BY 4.0).

http://creativecommons.org/licenses/by/4.0/

(c) (i) Open Access

\begin{abstract}
Owing to the favorable geographical location, Bangladesh captures a good amount of solar radiation per day. The proper utilization of this solar energy may reduce the country's energy demand to a great extent. Bangladesh government has already made a master plan to utilize the abundant solar energy in different ways with a capacity development target of $600 \mathrm{MW}$ by the end of 2021. Until 2018 a total capacity of $220 \mathrm{MW}$ of solar power could be achieved by installing 6.9 million solar home systems (SHSs). On the other way, rooftop solar and solar mini-grid projects facilitated the capacity of 3.07 MW and $5 \mathrm{MW}$, respectively. A capacity of $32 \mathrm{MW}$ could also be touched by solar irrigation projects with more than 1300 pumps for serving country's rural people, and solar-diesel hybrid solution program (by installing 138 small power stations) has been supporting the telecom operators. Bangladesh power development board (BPDB), and Infrastructure Development Company Limited (IDCOL) have been promoting numerous research-development solar projects to many governments and private universities to build sustainable energy equipped country.
\end{abstract}

\section{Keywords}

Solar Energy, Electricity, Bangladesh, Government, IDCOL, BPDP

\section{Introduction}

Bangladesh is a South Asian country having a total land area of $148,460 \mathrm{sq} . \mathrm{km}$ (57,320 sq. miles). The country has a large population of 162 million and ranked 8th position in the list of densely populated countries of the world [1]. The country again has very limited natural resources. However, inspite of having these limitations the economy of the country is still growing up day by day. However, in the last ten years the Gross Domestic Product (GDP) growth rate of 
Bangladesh is $6.5 \%$ turning out the country to be a middle-income country by the end of 2015 and again raised up to $8.15 \%$ in 2019 [2]. Moreover, Bangladesh possesses $0.58 \%$ contribution of the world's GDP due to its worth GDP of 302.57 billion US dollars reported by world bank in 2019 [3]. This impressive progress in economy is actually happened for its increase of industries specially export based business and opening new employments. The progressive economy of the country, and also the large population, on the other hand, are increasing the country's energy demand to a great extent. At present, the energy consumption per capita of the country is 344 kgoe (kilograms of oil equivalent), which has been raised by $22 \%$ from 2013 to 2019 [4] [5]. However, the energy consumption per capita in Bangladesh is still lower than that of other countries in South Asia as shown in Figure 1 [6]. Also, Bangladesh has lower electrical energy consumption per capita of $33 \mathrm{kWh})$ than that of any developed country like USA (11,730 $\mathrm{kWh}$ ) [7] [8]. Steady less power supply is a common issue for the people living even in capital or other industrial areas. Although Government is ramping up many electricity projects with new innovations, the electricity could not be well distributed due to enormous development of industries as well as the increase of populations. Therefore, it is highly demanded to increase per capita electricity generation of the country.

Natural Gas is the main source of generation of electricity in Bangladesh. According to a report of Bangladesh Power Development Board (BPDB), the country generates about $68 \%$ of its total electricity from natural gas [9]. The country is also depending on other fossil fuels sources such as diesel, furnace oil, coal, hydro and few renewable sources to generate electricity. Figure 2 shows the contributions of different types of fuel on the production of country's total electricity in the fiscal year (FY), 2019. From Figure 2 it is seen that the country produces only $0.05 \%$ electricity from renewable energy sources. Bangladesh is following the developed countries to reduce its carbon emission from the atmosphere enhancing the usage of its renewable resources for the generation of electricity. Bangladesh government has already taken many steps for this purpose

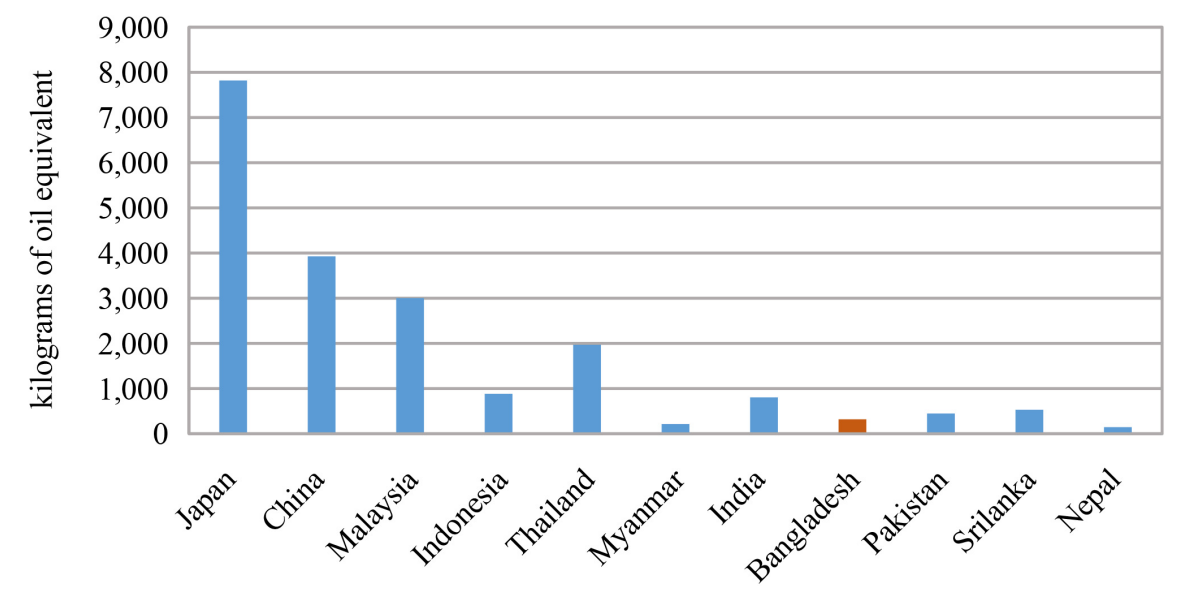

Figure 1. Energy consumption per capita in different countries of Asia. Source Ref. [6]. 


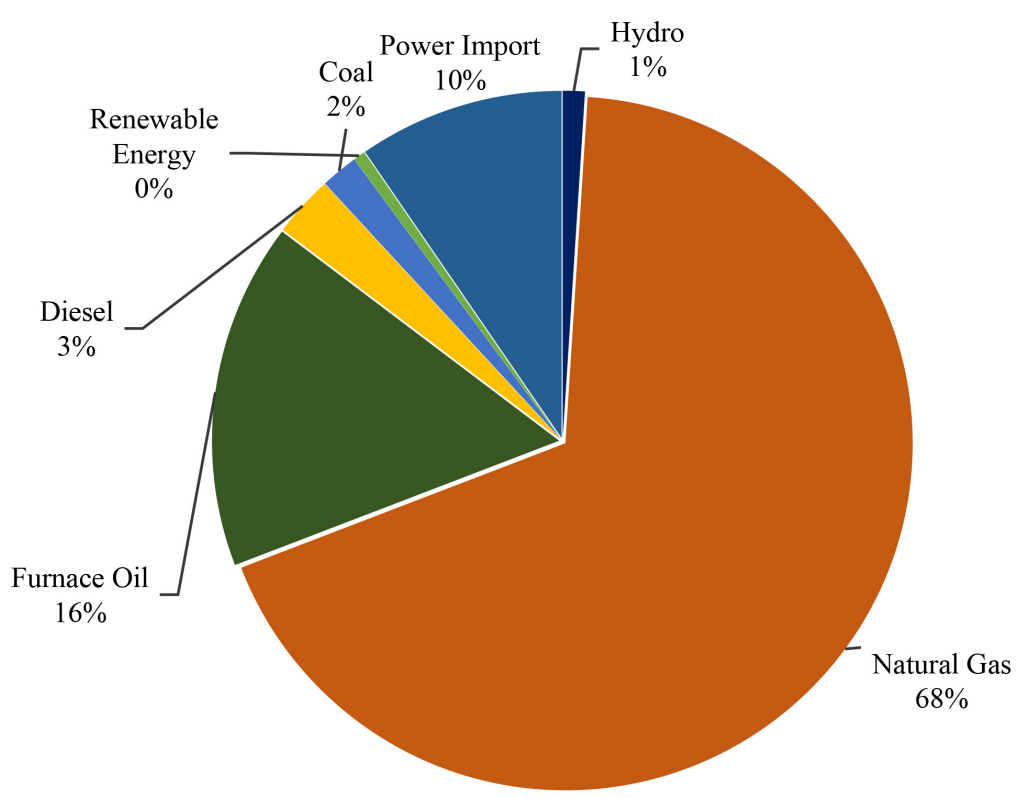

Figure 2. Fuel type contributions on electricity generation of Bangladesh. Source Ref. [9].

and targeted to produce $10 \%$ of the country's net electricity from the available renewable energy sources by the year 2021 [10] [11]. This study work is an attempt to show the present scenario of Bangladesh in utilization of its renewable energy resources, especially solar energy, as a green source of electric power generation. We explained the country's available source of renewable energy and its valuable prospects. And featured government's various initiatives of generating electricity from solar energy. It is seen that the country is reaching a milestone of generating solar electricity by applying solar home system, rooftop solar projects, solar minigrids, solar irrigation program, solar-diesel hybrid solution for Telecom, etc. Finally, we concluded by demonstrating several research-development solar projects of the government and non-government organizations of Bangladesh.

\section{Source of Renewable Energy in Bangladesh}

Recently, the use of renewable energy is getting much attention due to its sustainability, low carbon emission and almost lower production cost. They can be reused due to their inexhaustible properties [8] [12]. Bangladesh is much fortunate to have an enormous number of renewable energy sources, which can play a key role to meet up the ongoing and future energy demand of the country [13] [14]. The available sources of renewable energy of Bangladesh are solar, wind, biomass, hydro, biogas, geothermal, etc. [8] [15]. Bangladesh government has plans to produce $4190 \mathrm{MW}$ electricity from these natural energy sources by the year 2030. Table 1 shows the government's year-wise target of electricity production from different renewable energy sources [11].

\section{Prospects of Solar Energy in Bangladesh}

Solar energy is regarded as the most plentiful and potential sources of renewable 
Table 1. Government's year-wise target of electricity production from different renewable energy sources (MW). Source: Ref. [11].

\begin{tabular}{cccccccc}
\hline Year & Solar & Wind & Hydro & Biomass & Biogas & $\begin{array}{c}\text { Others } \\
\text { (Tidal, Wave) }\end{array}$ & Total \\
\hline Until 2018 & 350 & 2.9 & 230 & 0 & 1.08 & 0 & 583.98 \\
2019 & 84 & 0 & 0 & 0 & 1 & 0 & 85 \\
2020 & 100 & 38 & 0 & 0 & 2 & 0 & 140 \\
2021 & 120 & 80 & 0 & 15 & 3 & 0 & 218 \\
2022 & 150 & 120 & 0 & 15 & 4 & 0 & 289 \\
2023 & 165 & 170 & 0 & 15 & 4 & 0 & 354 \\
2024 & 165 & 170 & 0 & 15 & 4 & 0 & 354 \\
2025 & 165 & 170 & 0 & 15 & 4 & 2 & 356 \\
2026 & 165 & 170 & 0 & 15 & 4 & 4 & 358 \\
2027 & 165 & 170 & 0 & 15 & 4 & 6 & 360 \\
2028 & 165 & 170 & 0 & 15 & 4 & 8 & 362 \\
2029 & 165 & 170 & 0 & 15 & 5 & 10 & 365 \\
2030 & 165 & 170 & 0 & 15 & 5 & 10 & 365 \\
Total & 2124 & 1600.9 & 230 & 150 & 45.08 & 40 & 4189.98 \\
\hline
\end{tabular}

energy to all over the world [8] [16]. This energy can be utilized in two different processes: 1) Thermal; 2) Photovoltaic (PV) process. In thermal process the heat exhausted from solar energy is mainly stored for heating purpose, purifying water, generating power, etc. While in PV process the light (solar) energy is converted into electricity, which can be used for many purposes like lighting, pumping, delivering electricity in remote areas where grid electricity is not available, etc. [8] [17]. Solar PV system has been widely used for global electricity generation, sharing around $2.7 \%$ of total electricity generation [18]. The uses of solar PV system are increasing progressively in many countries to cross the Sustainable Development Scenario (SDS) level by 2030. In 2019 the amount of generated PV based electric power was 720 TW (global) and keeping this value as a reference it is estimated that an increase of 15\% (annually) of PV based electricity generation is required to obtain $3300 \mathrm{TW}$ (terawatt) by 2030 [18].

Due to its geographical location, Bangladesh has also high potentiality of applying solar irradiation to generate electricity. The country absorbs average solar radiation of 4.0 to $6.5 \mathrm{kWh} / \mathrm{m}^{2}$ per day, which is capable of producing $1018 \times$ $10^{18} \mathrm{~J}$ of energy [8] [12]. From this high amount of solar energy only $0.11 \%$ is used to meet the country's primary energy consumption. Figure 3 shows the average monthly solar radiation that falls on some selected districts of Bangladesh [19], whereas Figure 4 shows the average bright sunshine hours at the capital Dhaka City [20].

The abundant solar energy in Bangladesh may reduce the traditional fossil fuel-based power production. It may also ensure a green environment for future 


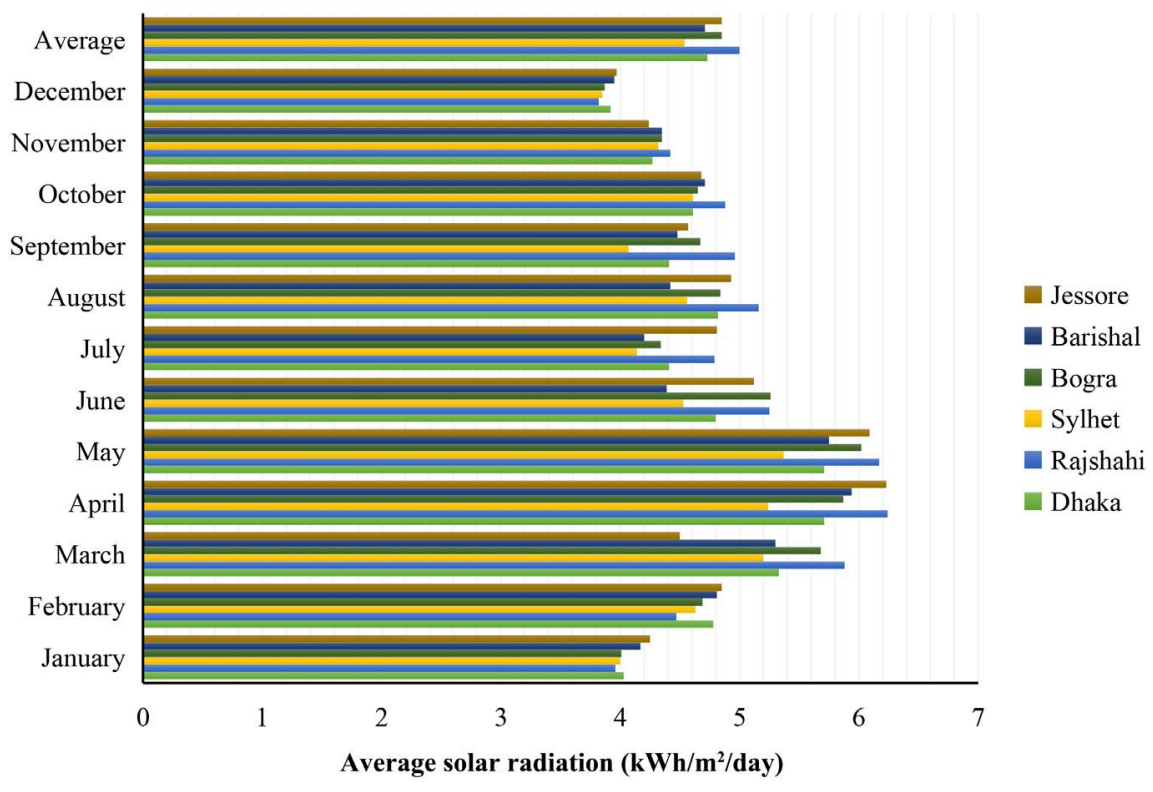

Figure 3. Solar radiation in some selected districts of Bangladesh. Source: Ref. [19].

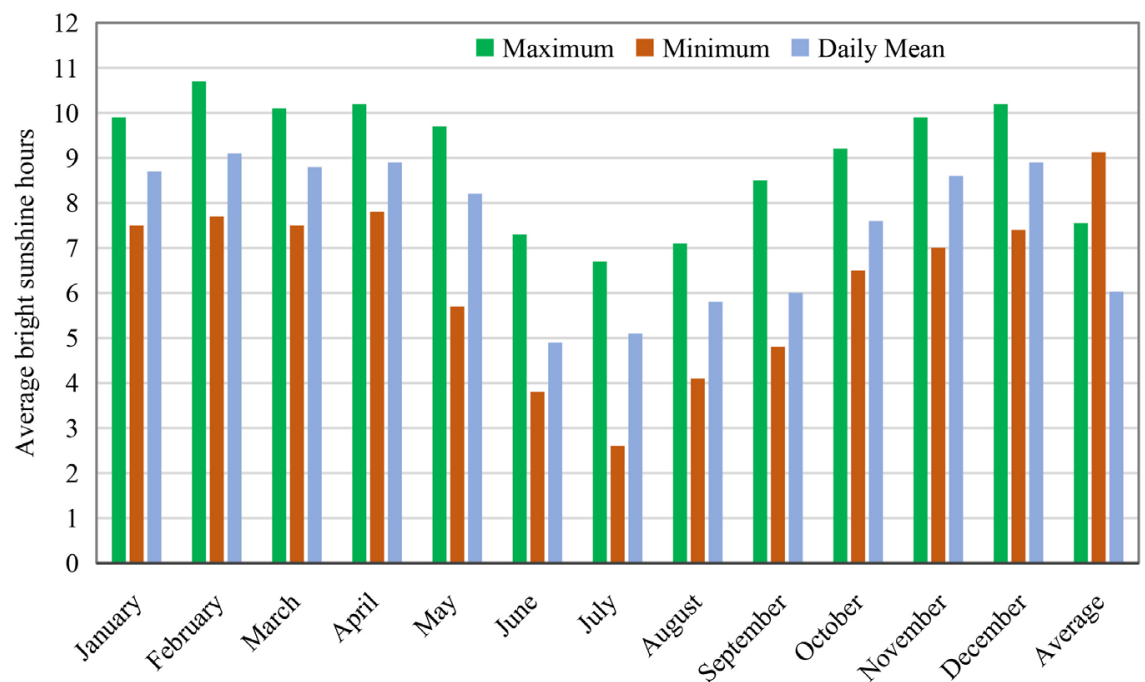

Figure 4. Per month bright sunshine hours at the Capital (Dhaka). Source: Ref. [20].

generations [15]. Hence, at present the government of Bangladesh is giving much importance on the usage of solar energy and conducting several activities through different public and private organizations [9].

\section{Government's Initiatives}

Bangladesh government has been giving high degree of priority on renewable energy to shape the country as an energy secured country with both sustainable (solar, wind, hydro, biomass, etc.) and conventional energy (oil, gas, coal, etc.) sources. It is expected that the government initiated various renewable energy-based schemes could be beneficial for the country to encounter its policy goals for secure, reliable and affordable energy access to its people [9]. In this 
regard BPDB and IDCOL (Infrastructure Development Company Limited) have taken various methodical steps to implement the government's renewable energy related projects to promote the energy efficiency of the country [9] [21].

The initiatives taken by BPDB and IDCOL in prompting the utilization of solar energy are described below.

\subsection{Solar Home System}

In Bangladesh, a large portion of total population live in rural and remote hilly areas, where still does not have the access to grid electricity. To satisfy the electricity demand of these people solar home systems (SHSs) has got much popularity due to its lower cost and easier installation facility [22]. IDCOL is playing the most significant role in this sector, it has started the SHS program in 2003 with a mission to fulfill the basic electricity demand of the electricity less rural people of Bangladesh as well as reaching the Government's vision of ensuring access to electricity for all residents by 2021 [21]. Until 2018, a total capacity of about $220 \mathrm{MW}$ could be installed by applying more than 6.8 million SHSs in different regions of the country [23]. Along with IDCOL different private organizations, such as Grameen Shakti, have also come forward to make the SHS program successful. Figure 5 insets the number of SHSs installed by IDCOL and different private organizations from 2003 to 2018.

The SHS program has become capable to provide solar electricity to about 18 million people of Bangladesh that is more than $11 \%$ of its total population who were mainly dependent on kerosene fuel for the lighting purpose [21]. This program also has been able to save the usage of 1.14 million tons of kerosene whose regular price is approximately 411 million USD. Furthermore, around 75,000 people have found the working opportunities through this program [21].

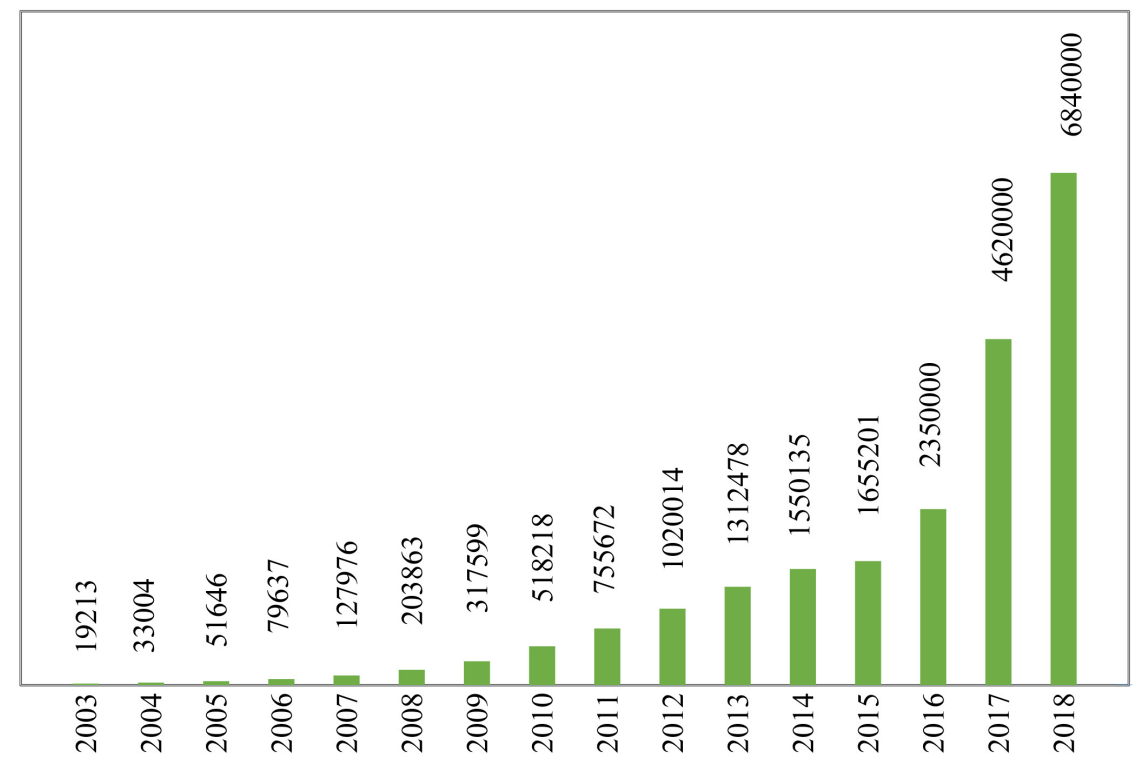

Figure 5. Total number of installed solar home systems in Bangladesh from 2003 to 2018. Source: Ref. [23]. 


\subsection{Rooftop Solar Projects}

Generally, 3.5 to 4 acres of land is required to install a $1 \mathrm{MW}$ solar based power plant. This enormous land consumption is actually appeared to be a huge challenge for a small but over populated country like Bangladesh. Therefore, the government of Bangladesh is encouraging to use the vacant spaces and rooftops of buildings for installing solar power generation plants [21].

Rooftop Solar Projects are the latest intervention of IDCOL for financing renewable energy projects. Under this financing scheme IDCOL provides necessary loan facilities, technical compliance monitoring, project development and performance monitoring supports. Up to July 2019, IDCOL has financed 11 rooftop solar projects, 4 of them have already come in operation with a total capacity of about 3.07 MW. IDCOL also has plans to finance a total capacity of 300 MW by 2022 [21].

BPDP is another government organization for handling the renewable energy projects. Until now it has implemented a remarkable number of solar projects and many of them are still going on. Table 2 shows some of the BPDP's implemented (fiscal year 2018-2019), ongoing and future solar projects. These solar projects of BPDP contain both grid tied and off-grid technologies [9].

\subsection{Solar Mini Grid Projects}

A small power station (grid) which generate electricity of few kilowatt $(\mathrm{kW})$ to

Table 2. Major solar projects implemented by BPDP. Source: Ref. [9].

a) Implemented Solar Projects (Fiscal Year 2018-2019)

\begin{tabular}{ll}
\hline Name of the Project & Location \\
\hline 7.4 MW Grid Connected Solar PV Power Plant & $\begin{array}{l}\text { Kaptai, Rangamati } \\
\text { City Corporations of Bangladesh } \\
\text { Solar Street Lighting Program in 8 City Corporations }\end{array}$ \\
$\begin{array}{l}\text { Cox's Bazar } \\
\text { MW (20MW AC) Solar Park }\end{array}$ & Tetulia, Panchagarh \\
\hline
\end{tabular}

b) Ongoing Solar Projects

\begin{tabular}{|c|c|}
\hline Name of the Project & Location \\
\hline $32 \mathrm{MW}$ (AC) Solar Park & Dharmapasha, Sunamganj \\
\hline 50 MW (AC) Solar Park & Gouripur, Mymensingh \\
\hline 200MW (AC) Solar Park & Teknaf, Cox's Bazar \\
\hline 200 MW (AC) Grid Tied Solar PV Power Project & Sundarganj, Gaibandha \\
\hline 30MW (AC) Solar Park & Gangachara, Rangpur \\
\hline 100 MW (AC) Solar Park & Mongla, Bagerhat \\
\hline \multicolumn{2}{|l|}{ c) Future Solar Projects } \\
\hline Name of the Project & Location \\
\hline $0.813 \mathrm{~kW}$ Grid Tied Rooftop Solar PV Project & Jamalpur \\
\hline 50 MW Grid Tied Solar Power Plant & Bariahaat \\
\hline 50 MW Grid Tied Solar Power Plant & Chuadanga \\
\hline 50 MW Grid Tied Solar Power Plant & Netrokona \\
\hline 100 MW Solar Photovoltaic Power Plant & Feni \\
\hline
\end{tabular}


$10 \mathrm{MW}$ is known as mini grid. Solar mini grid is getting popular to developing countries because it can provide solar panel generated electricity to the house owners (who installed) and the rest of generated electricity can be distributed to other consumers where access of electricity is unavailable. So far IDCOL has installed 26 solar mini grids with cumulative capacity of $5 \mathrm{MW}$. These mini grid projects have successfully provided electricity to approximately 16,000 beneficiaries who live in the rural areas of Bangladesh. The World Bank, JICA, USAID, $\mathrm{ADB}$, etc. are providing financial support to the solar mini grid projects of IDCOL [21].

\subsection{Solar Irrigation Program}

In Bangladesh, about 1.61 million pumps are used for irrigation purpose from which about 1.34 million (83\%) runs by diesel and about 0.27 million (16\%) by electricity. These pumps usually consume 900 million liters of diesel and $700 \mathrm{MW}$ of electricity per year [8]. However, installation of solar irrigation pumps can be an effective way of reducing this dependency on fossil fuel and grid electricity. To work with this, IDCOL has targeted to install 50,000 solar irrigation pumps by 2025 . Until October 2019, IDCOL has installed 1630 solar irrigation pumps, about 1,323 of the pumps have already started operation with a capacity of 32 MW and the remaining pumps will come into operation within a very short time [21].

\subsection{Solar-Diesel Hybrid Solution for Telecom BTS}

Since grid connection is absent in many remote areas of Bangladesh, power supply becomes challenging for the telecom operators. Particularly in these areas the telephone operators use diesel generators for generating power, which again require periodical refueling and frequent maintenance. This in turn has forced the operators to use solar power as the alternative source of energy. A good number of telephone operators have already started to conduct off-grid BTSs with solar-diesel hybrid power system, which mainly uses solar PV as the primary source of power and diesel generator as the backup source. Until now, IDCOL has provided fund to almost 138 power stations that are operated by solar-diesel hybrid system in the telecom sector of Bangladesh [21].

\subsection{Research and Development (R\&D) Projects}

IDCOL has taken 1 million USD fund from the World Bank in order to support several $R \& D$ projects for improving the available renewable energy technologies and also for developing latest renewable energy sectors for Bangladesh. Under this grant scheme, IDCOL has funded 13 projects of different research groups to create different $\mathrm{R} \& \mathrm{D}$ opportunities [21].

IDCOL has provided fund to four individual research groups of United International University (UIU) for four different projects. One of these research teams is working to build a hybrid mini cold storage and to study the financial 
compatibility of making cold storage while another team is working to construct solar PV panel energized boats. Third team is working to develop a smart solar irrigation monitoring system and the fourth team is trying to establish a strong and affordable DC nano-grid for household and other productive uses. Besides, some other teams from different universities and research organizations are performing their research activities on solar technologies under the funding scheme of IDCOL [21].

So far, BRAC University has been able to make 15 solar energized electric rickshaw-vans (human hauler, ambulance, cargo). A team of Dhaka University of Engineering \& Technology (DUET) has designed a thermal energy storage system by employing relevant Phase Changing Material (PCM). 'Solar E Technology', a solar company of Bangladesh, has established a number of solar powered battery charging booths for small electric vehicles like easy bike, electric auto-rickshaw, etc. Also, with the financial support of IDCOL, the scientists of Bangladesh Atomic Energy Commission (BAEC) are working to fabricate dye sensitized solar cells (DSSCs) by utilizing the local technology and resources [21].

\section{Conclusion}

The energy demand in Bangladesh is growing up day by day due to rapid urbanization, mechanization and industrialization. Moreover, about $30 \%$ of its total inhabitants who live in the rural areas are still out of grid electricity. This energy scarcity can be minimized by generating electricity from renewable energy sources, especially solar energy. The government of Bangladesh has already started to conduct several activities through IDCOL and BPDP for producing electricity from solar radiation. IDCOL and some other private organizations have installed more than 6.9 million SHSs having a total capacity of $220 \mathrm{MW}$. BPDP has also taken many steps to establish a good number of solar parks and solar PV power plants. Besides, a number of research teams from different universities and research organizations are working to develop the existing renewable technologies under the financing scheme of IDCOL. However, more efforts and funds need to be provided in this sector to promote the development and research activities in order to attain the intended electricity generation capacity from solar energy. Along with this, Bangladesh should also take necessary steps to encourage people for using solar PV systems as their primary source of energy so as to reduce the stress on grid power supply.

\section{Conflicts of Interest}

The authors declare no conflicts of interest regarding the publication of this paper.

\section{References}

[1] Central Intelligence Agency (CIA) (2020) South Asia: Bangladesh-The World Factbook. https://www.cia.gov/the-world-factbook/countries/bangladesh/ 
[2] Bangladesh Bank (2019) Annual Report 2018-2019. https://www.bb.org.bd/pub/annual/anreport/ar1819/index1819.php

[3] (2020) Bangladesh GDP 1960-2019 Data. https://tradingeconomics.com/bangladesh/gdp

[4] Hydrocarbon Unit (2019) Hydrocarbon Unit, Energy and Mineral Resources Division under the Ministry of Power, Energy and Mineral Resources of Bangladesh. https://www.hcu.org.bd/

[5] WorldData.info (2019) Energy Consumption in Bangladesh. https://www.worlddata.info/asia/bangladesh/energy-consumption.php

[6] The World Bank (2014) Energy Use. http://data.worldbank.org/indicator/EG.USE.PCAP.KG.OE

[7] IndexMundi (2020) Electricity Consumption Per Capita by Country-World, Thematic Map. https://www.indexmundi.com/map/?v=81000

[8] Baky, M.A.H., Rahman, M.M. and Islam, A.K.M.S. (2017) Development of Renewable Energy Sector in Bangladesh: Current Status and Future Potentials. Renewable and Sustainable Energy Reviews, 73, 1184-1197. https://doi.org/10.1016/j.rser.2017.02.047

[9] Bangladesh Power Development Board (BPDB) (2019) Annual Report 2018-2019. https://www.bpdb.gov.bd/bpdb

[10] Karim, M.E., Karim, R., Islam, M.T., Muhammad-Sukki, F., Bani, N.A. and Muhtazaruddin, M.N. (2019) Renewable Energy for Sustainable Growth and Development: An Evaluation of Law and Policy of Bangladesh. Sustainability, 11, 5774. https://doi.org/10.3390/su11205774

[11] Sustainable and Renewable Energy Development Authority (SREDA) (2019) Annual Report 2018-2019, Sustainable and Renewable Energy Development Authority (SREDA), Bangladesh. http://www.sreda.gov.bd/

[12] Halder, P.K., Paul, N., Joardder, M.U.H. and Sarker, M. (2015) Energy Scarcity and Potential of Renewable Energy in Bangladesh. Renewable and Sustainable Energy Reviews, 51, 1636-1649. https://doi.org/10.1016/j.rser.2015.07.069

[13] Uddin, M.N., Rahman, M.A., Mofijur, M., Taweekun, J., Techato, K., Rasul, M.G. (2019) Renewable Energy in Bangladesh: Status and Prospects. Energy Procedia, 160, 655-661. https://doi.org/10.1016/j.egypro.2019.02.218

[14] Ahmed, S., Islam, M.T., Karim, M.A. and Karim, N.M.J.R.E. (2014) Exploitation of Renewable Energy for Sustainable Development and Overcoming Power Crisis in Bangladesh. Renewable Energy, 72, 223-235. https://doi.org/10.1016/j.renene.2014.07.003

[15] Hossain, M. (2015) Achieving Sustainable Energy Targets in Bangladesh. The Magazine of the United Nations.

https://www.un.org/en/chronicle/article/achieving-sustainable-energy-targets-bangl $\underline{\text { adesh }}$

[16] Kumar, A., Kumar, K., Kaushik, N., Sharma, S. and Mishra, S. (2010) Renewable Energy in India: Current Status and Future Potentials. Renewable and Sustainable Energy Review, 14, 2434-2442. https://doi.org/10.1016/j.rser.2010.04.003

[17] ONE (2020) Energy: The Challenge. https://www.one.org/international/issues/

[18] International Energy Agency (2020) Solar PV Analysis. https://www.iea.org/reports/solar-pv

[19] Islam, M. (2002) Assessment of Renewable Energy Resources of Bangladesh. http://www.geni.org/globalenergy/library/energytrends/currentusage/renewable/wi 
$\underline{\text { nd/global-wind-resources/bangladesh/bangladesh.pdf }}$

[20] Islam, M.R., Islam, M.R. and Beg, M.R.A. (2008) Renewable Energy Resources and Technologies Practice in Bangladesh. Renewable and Sustainable Energy Reviews, 12, 299-343. https://doi.org/10.1016/j.rser.2006.07.003

[21] Infrastructure Development Company Limited (IDCOL), Bangladesh. https://idcol.org/home/penergy

[22] Islam, M.Z., Shameem, R., Mashsharat, A., Mim, M.S., Rafy, M.F., Pervej, M.S. and Ahad, M.A.R. (2014) A Study of Solar Home System in Bangladesh: Current Status, Future Prospect and Constraints. 2nd International Conference on Green Energy and Technology, Dhaka, Bangladesh, 5-6 September 2014, 110-115. https://doi.org/10.1109/ICGET.2014.6966674

[23] Masud, M.H., Nuruzzaman, M., Ahamed, R., Ananno, A.A. and Tomal, A.N.M.A. (2020) Renewable energy in Bangladesh: Current Situation and Future Prospect. International Journal of Sustainable Energy, 39, 132-175.

https://doi.org/10.1080/14786451.2019.1659270 